\title{
Histological and Immunohistochemical Analysis of Green Coffee Aqueous Extract Effect on Parotid Salivary Gland in Streptozotocin Induced Diabetic Albino Rats
}

\author{
Original \\ Article \\ Yasmin M. El-Ghazawy', Medhat A. El-Zainy ${ }^{2}$, Rabab Hassan ${ }^{2}$ \\ ${ }^{I}$ Department of Oral Biology, Faculty of Oral and Dental Medicine, Future University in \\ Egypt, Cairo, Egypt \\ ${ }^{2}$ Department of Oral Biology, Faculty of Dentistry, Ain Shams University, Cairo, Egypt
}

\begin{abstract}
Background: Diabetes mellitus (DM) is a very common disorder of carbohydrate metabolism whose complications affect widely the quality of life, longevity and healthcare costs. Green coffee is one of the most consumed beverages worldwide and is one of the main sources of chlorogenic acid (CGA) especially in its green form with various biological benefits.

Aim: To evaluate the possible effect of green coffee beans aqueous extract on parotid gland (PG) of streptozotocin (STZ) induced diabetic albino rats.

Material and Methods: Forty two adult male albino rats were divided equally into 3 main groups. Group I (control) rats received $0.2-0.25 \mathrm{ml}$ citrate buffer. This group was subdivided equally into 2 subgroups IA and IB in which rats were sacrificed corresponding to their experimental subgroups. Group II (diabetic) rats were injected by single dose of STZ (40mg/kg). Group III (diabetic treated) rats were received green coffee at a dose of $93 \mathrm{mg} / \mathrm{kg}$ in form of aqueous extract $1.24-1.55 \mathrm{ml}$ orally once a day from the development of diabetes till the day of sacrifice. In groups II and III rats were subdivided into subgroups A and B (rats sacrificed after 1 and 2 weeks of diabetes development respectively). PGs were dissected and examined histologically and immunohistochemically.

Results: Histologically, serous acini of group II showed histological deterioration in form of pleomorphic nuclei and cytoplasmic vacuolations. In group III, serous acini showed less nuclear changes and minimal vacuolations. Immunohistochemically, PGs of group II showed diffuse cytoplasmic reactions of caspase-3 in their parenchymal elements, while the nuclear reactions were localized in group III. Statistically, area\% of both anti-active caspase-3 antibody and inter-acinar spaces showed significant increase in subgroup IIB and significant decrease in subgroup IIIB.

Conclusions: Green coffee aqueous extract can enhance the deteriorative effects of diabetes on PGs in time dependent manner.
\end{abstract}

Received: 09 December 2019, Accepted: 25 December 2019

Key Words: Caspase-3; diabetes; green coffee; parotid gland; streptozotocin.

Corresponding Author: Rabab Hassan, PhD, Department of Oral Biology, Faculty of Dentistry, Ain Shams University, Cairo, Egypt, Tel.: +20 1224101540, E-mail: rabab@asfd.asu.edu.eg

ISSN: $1110-0559$, Vol. 43, No.3

\section{INTRODUCTION}

Diabetes mellitus (DM) is a long life endocrine system disorder and is clinically characterized by hyperglycemia that induces oxidative damage through production of reactive oxygen species (ROS) mediating cellular apoptosis ${ }^{[1]}$. Development of diabetes is associated with disturbance of carbohydrates, protein, and fat metabolism due to autoimmune destruction of the pancreas cells with subsequent insulin deficiency or resistance to insulin action as a result of reduced tissue responses to insulin ${ }^{[2,3]}$. DM affects salivary glands (SGs) structure and function leading to reduction in amount of saliva produced and so multiple complications can be raised up in the oral cavity by giving permission to a lot of bacterial aggregation that cause multiple oral deteriorations, alteration in the food taste, halitosis and abundant caries ${ }^{[4]}$.
Herbal products have received great consideration for management of DM and its complications. One of the most consumed herbal beverages worldwide is coffee. Unroasted coffee beans are termed green coffee beans (GCBs). Consumption of GCBs aqueous extract produced several positive biological effects as antihypertension, anticancerous, antidiabetic, inhibition of fat accumulation and modulation of glucose metabolism. Those biological effects have been accredited to chlorogenic acid (CGA) that present in green coffee $\mathrm{e}^{[5,6,7]}$.

This study was designed to detect the possible effect of GCBs aqueous extract on parotid gland (PG) in streptozotocin (STZ) induced diabetic albino rats at different durations by statistical analysis of predicted apoptotic rate and acini morphometry. 


\section{MATERIAL AND METHODS}

\section{Animals}

Forty two adult male albino rats were used in this study weighing between 200-250gm. The rats were housed in separate cages, five rats per cage in Ain Shams animal house under controlled environment (temperature $25 \pm 2{ }^{\circ} \mathrm{C}$ and $12 \mathrm{~h}$ dark/light cycles) and fed standardized diet consisting of fresh vegetables, dried bread and tap water throughout the experimental period. The experiment was conducted according to the recommendations and approval of ethics committee at Faculty of Dentistry, Ain Shams University, Egypt FDASU-REC IM 011701.

\section{Preparation of Aqueous GCB Extract}

$3 \mathrm{gm}$ bags of premium quality GCBs were obtained from local market, manufactured by (El-Sharq factory for Pharmacia Company). The aqueous extract was made by using $15 \mathrm{gm}$ of GCBs boiled in $100 \mathrm{ml}$ of distilled water for $15 \mathrm{~min}$ then filtered through sterile gauze ${ }^{[5]}$.

\section{Animal Grouping}

The rats were randomly divided into 3 main groups of 14 rats each as follows:

Group I (control): Rats were received $0.2-0.25 \mathrm{ml}$ citrate buffer (Sigma, St. Louis, MO, USA). This group was subdivided equally into 2 subgroups IA and IB in which rats were sacrificed corresponding to their experimental subgroups.

Group II (Diabetic): Rats were injected by single dose of STZ 40mg/kg (Sigma, St. Louis, MO, USA) dissolved in citrate buffer $0.2-0.25 \mathrm{ml}$ intraperitoneally for induction of diabetes type ${ }^{\left[{ }^{[8]}\right.}$. Three days after STZ injection, blood glucose levels were measured in tail vein blood samples by glucometer after an overnight fast 12-14h. A plasma glucose level greater than $300 \mathrm{mg} / \mathrm{dl}$ was confirmed by the occurrence of diabetes.

Group III (Diabetic Treated): Rats were received green coffee at a dose of $93 \mathrm{mg} / \mathrm{kg}$ in form of aqueous extract $1.24-1.55 \mathrm{~m}$ orally once a day from the development of diabetes till the day of sacrifice ${ }^{[5]}$

In group II and III rats were subdivided into 2 subgroups; A and B in which rats were sacrificed after 1 and 2 weeks of diabetes development respectively.

At the end of each experimental period, the rats sacrificed by high dose of anesthetic agent (ketamine). The PGs dissected and prepared for light microscopic examination using hematoxylin and eosin (H\&E) stain and immunohistochemical localization of anti-active caspase-3 antibody.

\section{H\&E Stain}

Specimens were fixed in $10 \%$ neutral formalin for $48 \mathrm{~h}$, washed properly under running water, dehydrated by ascending concentrations of alcohol, then transferred to xylol, then infiltrated and embedded in the center of paraffin wax blocks. The embedded specimens were sectioned by microtome (5um thick), transferred in descending concentrations of alcohol then distilled water, finally the sections were stained by (H\&E) stain (Sigma, St. Louis, MO, USA) ${ }^{[9]}$.

\section{Immunohistochemical Localization of Anti-active Caspase-3 Antibody}

In rehydreated paraffin-embedded section endogenous peroxidase activity was blocked by incubating them in $3 \%$ hydrogen peroxide $\left(\mathrm{H}_{2} \mathrm{O}_{2}\right)$ in methanol at $23^{\circ} \mathrm{C}$ for $15 \mathrm{~min}$, then microwaved in citrate buffer $(\mathrm{PH} \mathrm{6.0)}$ ) for 9 min. After that, polyclonal rabbit anti-active caspase-3 $(1: 100)$ in phosphate buffer saline (PBS) from (Biocare Medical company, Concord, Calif., USA), was applied for $60 \mathrm{~min}$ at $23^{\circ} \mathrm{C}$ then, secondary biotinylated goat anti-rabbit antibody (Sigma, St. Louis, MO, USA) was applied for 30min (1:200). Slides were then incubated and developed with diamminobenzidine and counterstained with hematoxylin ${ }^{[10]}$.

Examination of both $\mathrm{H} \& \mathrm{E}$ and active caspase-3 stained sections was done using light microscope (Model BX40F4, 7E12569) Olympus Optical co., LTD. Japan. Fields photographing was done using a mounted camera (Olympus soft imaging solutions, munster, Germany, Model LC20, 59001227) at magnification (x400).

\section{Histomorphometric Analysis}

All steps for area percentage (area $\%)$ calculation of caspase- 3 and inter-acinar space were carried out on photomicrographs captured at magnification of $x 400$ from three different representative fields of each slide from each rat in all groups. The image analysis system was used to assess the area $\%$ of anti-active caspase- 3 antibody and the distances between each acinus in the studied specimens. For caspase- 3 area $\%$, in each field, after grey calibration, the image was transformed into a grey delineated image to choose areas showing positive reactivity. Areas of positive reaction were then masked by a blue binary color. Dimensions were converted from pixels to millimeter by the software. The process was repeated for inter-acinar space calibration. At last, mean values were obtained for each specimen. All calculations of the area\% were performed in relation to a standard measuring frame of an area $0.19 \mathrm{~mm}^{2}$. Images were then transferred to the computer system for analysis using image analysis software (Image, 1.41a, $\mathrm{NIH}$, USA) and then, the obtained data were statistically analyzed.

\section{Statistical Analysis}

Numerical data were explored for normality by checking the distribution of data and using tests of normality (Kolmogorov-Smirnov and Shapiro-Wilk tests). Data showed non-normal (non-parametric) distribution. Data were presented as median, range, mean and standard deviation values. Kruskal-Wallis test was used to compare between the groups. Dunn's test was used for pair- 
wise comparisons. Mann-Whitney $U$ test was used for comparison between follow up times. The significance level was set at $P \leq 0.05$. Statistical analysis was performed with IBM SPSS Statistics for Windows, Version 20.0. Armonk, NY: IBM Corp.

\section{RESULTS}

\section{Histological Results}

\section{Group I (control)}

There was no histological difference between both subgroups. Rats' PG showed normal histological features of parenchymal elements. The gland was formed of spherical shaped pure serous acini with pyramidal cells and rounded basally situated nuclei. Intercalated duct (ID) lined by cuboidal cells with basophilic cytoplasm and centrally placed rounded nuclei (Figure 1a). Striated duct (SD) was lined by columnar cells with central placed nuclei, eosinophilic cytoplasm and basal eosinpophilic striations (Figure 1b). Excretory duct (ED) was lined by pseudostratified columnar epithelium with goblet cell and surrounded by dense fibrous connective tissue (C.T) (Figure 1c).

\section{Group II (Diabetic group)}

Subgroup IIA: PGs revealed nuclei of serous acini with hyperchromatism, pyknosis and pleomorphism with intracellular cytoplasmic vacuoles. ID showed nearly normal histological appearance (Figure 2a). SD cells were flattened with apparent loss of basal striations (Figure 2b). ED cells showed loss of pseudostratification in some areas, flattening of cells and discontinuity in epithelium. The ED was surrounded by hyalinized areas of C.T and congested blood vessels (B.Vs) (Figure 2c).

Subgroup IIB: PGs revealed serous acini with similar changes as subgroup IIA in addition to ill-defined outline with increased inter-acinar spaces and desquamated cells between acini. ID appeared flattened cell lining with nuclear degeneration (Figure 2d). SD showed decrease in cell height, loss in basal striations and the lumen was filled with stagnated secretion. The duct was surrounded by enlarged and congested B.Vs (Figure 2e). ED appeared with discontinuity in epithelium, stagnated secretion in the duct lumen, the duct was surrounded by hyalinized C.T with enlarged and congested B.Vs (Figure 2f).

\section{Group III (diabetic treated)}

Subgroup IIIA: Some acinar cells showed few cytoplasmic vacuoles with pyknotic, hyperchromatic and pleomorphic nuclei. Some ID appeared with normal histology while other showed flattened cells lining and nuclear degeneration (Figure 3a). SD showed decrease in cell height with loss of basal striation and stagnated secretion in lumen (Figure $3 b$ ). ED showed normal appearance of pseudostratification in some areas while loss of pseudostratification and flattening of the cells in other areas, the duct was surrounded by dens fibrous C.T and congested B.Vs (Figure 3c).
Subgroup IIIB: Serous acini showed almost normal histological appearance with minimal vacuolations, while others contain hyperchromatic and pleomorphic nuclei. ID was lined by cuboidal cells (Figure 3d). SD with columnar cells and basal striation was detected (Figure 3e). ED lined by psuedostratified epithelium that surrounded by wellorganized C.T and normal B.Vs was seen (Figure 3f).

\section{Immunohistochemical Results}

\section{Group I (Control group)}

Rats' PG in both subgroups revealed serous acini with few areas of localized positive cytoplasmic reaction and localized nuclear reaction, ID with positive cytoplasmic and nuclear reaction, while SD showed negative cytoplasmic and nuclear reaction (Figure 4a). ED appeared with localized area of positive cytoplasmic and nuclear reaction (Figure 4b).

\section{Group II (Diabetic group)}

Subgroups IIA and IIB showed diffuse areas of positive cytoplasmic reaction in serous acini and ID (Figures 5a\&d), SD showed diffuse positive cytoplasmic and nuclear reaction (Figures 5b\&e), in addition to the positive reaction of the B.V in subgroup IIB (Figure 5e). ED showed diffuse positive cytoplasmic and few nuclear reactions (Figures $5 \mathrm{c} \& \mathrm{f}$ ). The reactions were more pronounced in subgroup IIB.

\section{Group III (diabetic treated)}

Subgroup IIIA: Revealed diffuse positive cytoplasmic reaction and localized nuclear reaction in serous acini and ID (Figure 6a). SD (Figure 6b) and ED (Figure 6c) showed positive cytoplasmic and nuclear reaction.

Subgroup IIIB: Serous acini and SD appeared with positive nuclear and cytoplasmic reaction, while ID showed negative nuclear and cytoplasmic reaction (Figure 6d). ED showed positive diffuse cytoplasmic and localized nuclear reaction (Figure 6e).

\section{Statistical Results}

\section{Anti-active Caspase-3 Antibody Area\%}

\section{Comparison Between Groups}

After 1 week, there was a statistically significant difference between the groups. Pair-wise comparisons revealed that there was no statistically significant difference between diabetic and treated groups; both showed statistically significantly higher caspase-3 area $\%$ than control group (Table 1, Figure 7a). After 2 weeks, there was a statistically significant difference between the groups. Pair-wise comparisons revealed that diabetic group showed the statistically significantly highest median caspase-3 area\%. Treated group showed statistically significantly lower median value. Control group showed the statistically significantly lowest caspase-3 area $\%$ (Table 1, Figure 7b). 


\section{Comparison at Different Duration Within Each Group (Effect of time)}

In both control and treated groups, there was no statistically significant change in median caspase-3 area\% after 2 weeks, while in diabetic group there was a statistically significant increase in median caspase- 3 area $\%$ after 2 weeks (Table 2, Figure 7c).

\section{Inter-acinar Space Area\%}

\section{Comparison Between Groups}

After 1 week, there was no statistically significant difference between all groups control, diabetic and treated (Table 3, Figure 8a). After 2 weeks, there was a statistically significant difference between the groups. Pair-wise comparisons revealed that diabetic group showed the statistically significantly highest median inter-acinar space area\%. There was no statistically significant difference between treated and control groups; both showed statistically significantly lower inter-acinar space area $\%$ than diabetic group (Table 3, Figure 8b).

\section{Comparison at Different Duration Within Each Group (Effect of time)}

In both control and treated groups, there was no statistically significant change in median inter-acinar space area\% after 2 weeks. In diabetic group, there was a statistically significant increase in median inter-acinar space area\% after 2 weeks (Table 4, Figure 8c).

\section{Correlation Between Caspase-3 Area\% and Inter- Acinar Space Area\%}

After 1 week, there was no statistically significant correlation between caspase-3 area\% and inter-acinar space area\% (Table 5, Figure 9a). After 2 weeks, there was a statistically significant direct correlation between caspase- 3 area\% and inter-acinar space area\% (Table 5, Figure 9b).
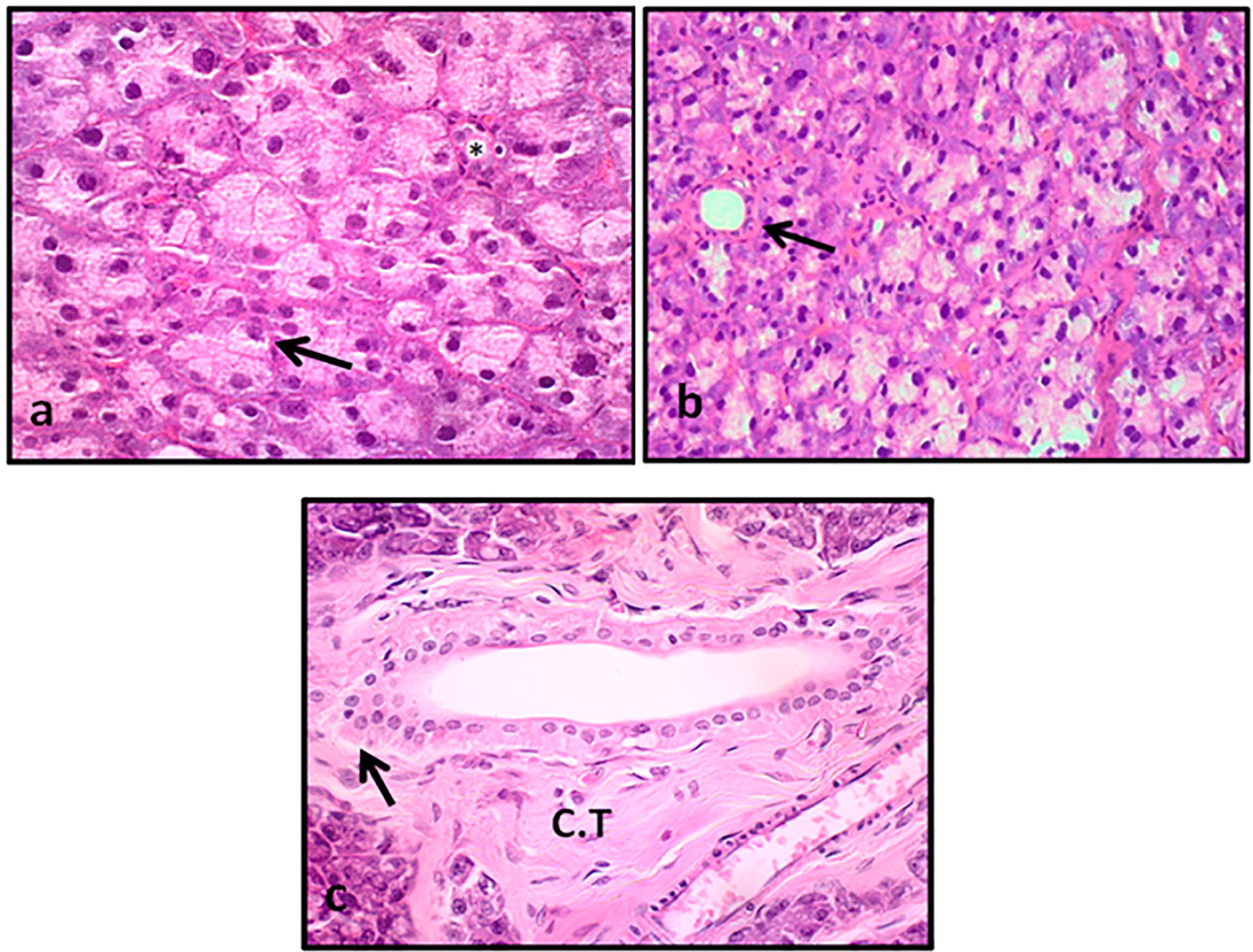

Fig. 1: A photomicrograph of PG of control group: a- Serous acini lined by pyramidal cells with basophilic cytoplasm and basally situated rounded nuclei (black arrow). ID lined by cuboidal cells with rounded nuclei (*). b- SD lined by columnar cells with centrally placed nuclei and eosinophilic cytoplasm (black arrow). c- ED lined by pseudostratified columnar epithelium (black arrow) surrounded by fibrous C.T. (C.T) (H\&E original magnification x400). 

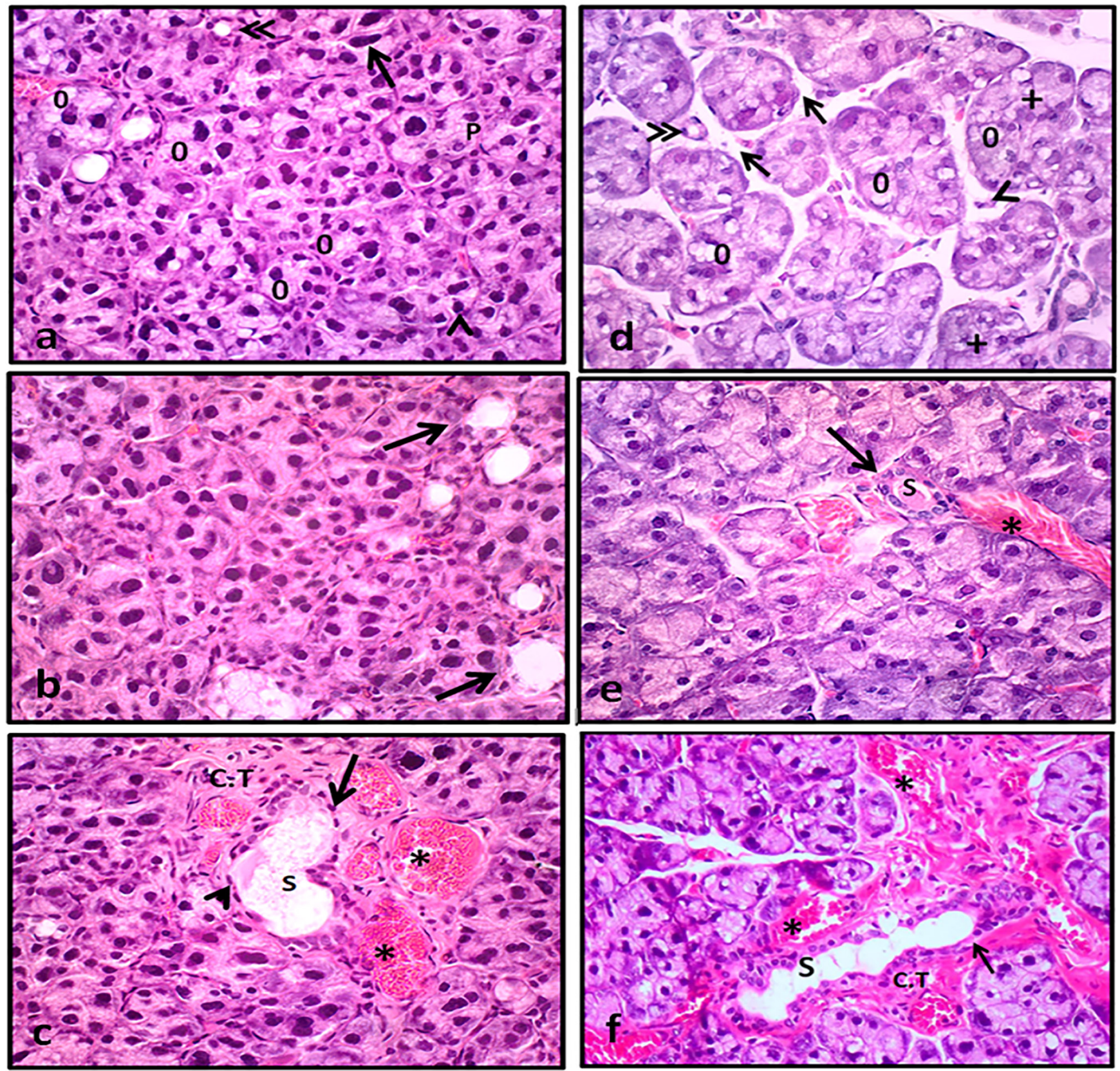

Fig. 2: A photomicrograph of PG of subgroup (IIA) a- Nuclei of serous acini appeared hyperchromatic (black arrow head), pyknotic (p) and pleomorphic (black arrow). Acinar cells showed cytoplasmic vacuoles (0). ID with normal appearance (double arrow head). b- SD with flattened cells, loss of basal striations (black arrows). c- ED cells with loss of pseudostratification (black arrow). Flattened cells (black arrow head). Stagnated secretion in the duct lumen (S). Hyalinized areas of C.T (C.T). Dilated and congested B.Vs $\left(^{*}\right)$. In subgroup (IIB) d- Serous acini with ill-defined outline $(+)$ and spaces appear between acini (black arrows). Acinar cells with cytoplasmic vacuoles (0). Desquamated cells between acini (black arrow head). ID shows flattened cell lining and nuclear degeneration (double arrow head). e- SD with decrease in cell height and loss in basal striations (black arrow). Lumen with stagnated secretion (S). Enlarged congested B.Vs $(*)$. f- ED with discontinuity in epithelium (black arrow). Stagnated secretion in the duct lumen (S). Hyalinized C.T (C.T). Enlarged and congested B.Vs $(*)(H \& E$ original magnification $\mathrm{x} 400)$. 

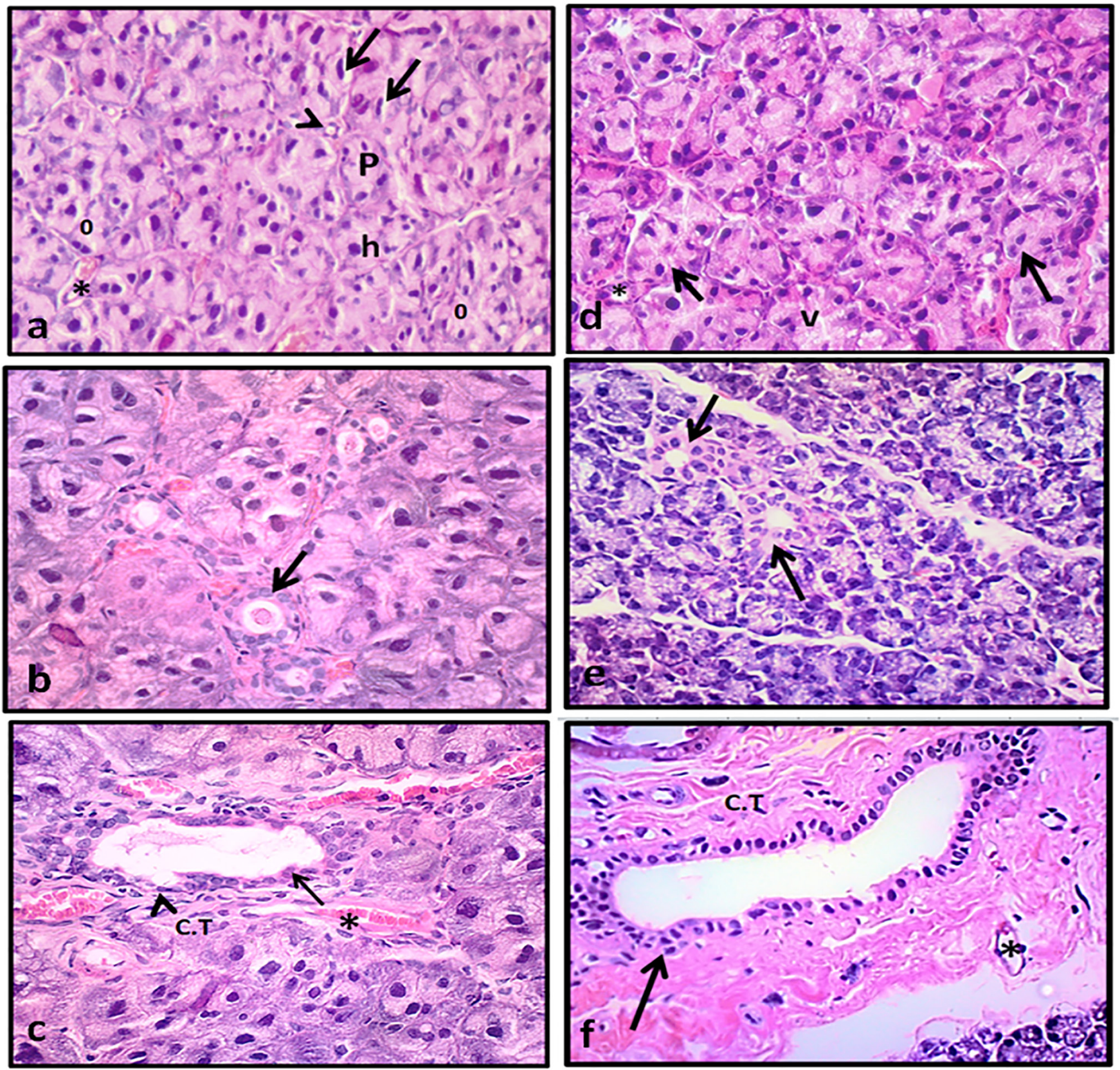

Fig. 3: A photomicrograph of PG of subgroup (IIIA) a- acinar cells with cytoplasmic vacuoles (0). Hyperchromatic (h), pyknotic (p) and pleomorphic (black arrows) nuclei. Some ID duct with cuboidal cell and rounded nuclei (Black arrow head) while other showing flattened cells lining and nuclear degeneration $(*)$. b- SD with decrease in cell height and loss of basal striation (black arrow). c- ED with normal pseudostratification in some areas (black arrow) and flattened cells in other areas (black arrow head). ED surrounded by C.T (C.T) and congested B.Vs (*). In subgroup (IIIB) d- Some serous acini with well-defined cell outline and basophilic cytoplasm (black arrow). Minimal vacuolations are detected (V). ID lined with cuboidal cells (*). e- SD with columnar cells (black arrows). $\mathrm{f}-\mathrm{ED}$ lined by psuedostratified epithelium (black arrow) that is surrounded by C.T (C.T) and normal B.Vs $(*)$ (H\&E original magnification $\mathrm{x} 400)$. 

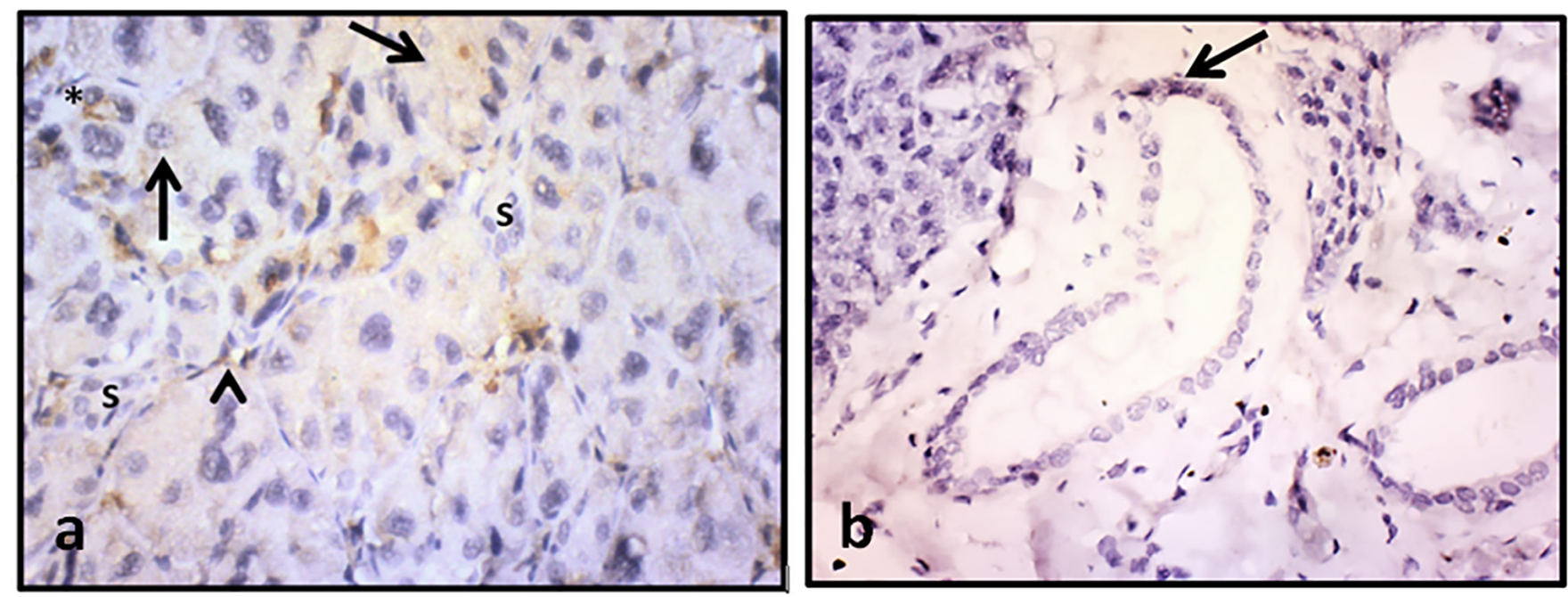

Fig. 4: A photomicrograph of PG of control group a- Serous acini with few areas of localized cytoplasmic reaction (black arrows) and localized nuclear reaction $(*)$. ID with positive cytoplasmic and nuclear reaction (black arrow head). SD with negative cytoplasmic and nuclear reaction (s). b- ED with localized area of positive cytoplasmic and nuclear reaction (black arrow) (anti-active caspase-3 antibody original magnification $\mathrm{x} 400$ ).
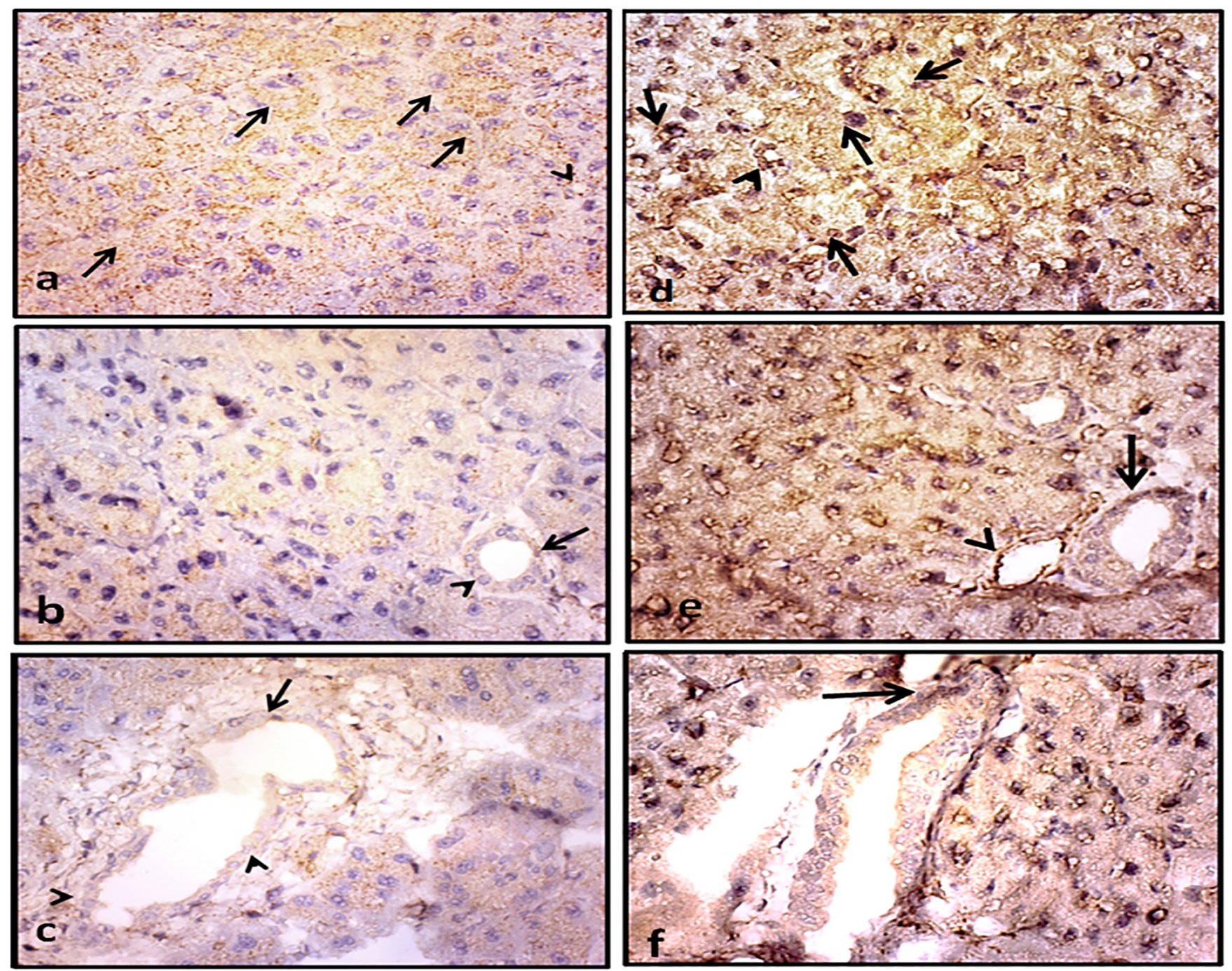

Fig. 5: A photomicrographs of PG of subgroup (IIA) a- Diffuse areas of positive cytoplasmic reaction in serous acini (black arrows) and ID (black arrow head). b- Positive cytoplasmic (black arrow head) and nuclear reaction in SD (black arrow). c- ED with positive cytoplasmic (black arrow head) and nuclear reaction (black arrow). In subgroup (IIB) d- Diffuse positive cytoplasmic and nuclear reaction in serous acini (black arrows) and ID (black arrow head). e- SD with positive diffuse cytoplasmic and localized nuclear reaction (black arrow). Blood vessel with positive nuclear and cytoplasmic reaction (black arrow head). fDiffuse positive cytoplasmic and localized nuclear reaction in ED (black arrow) (anti-active caspase-3 antibody original magnification x400). 

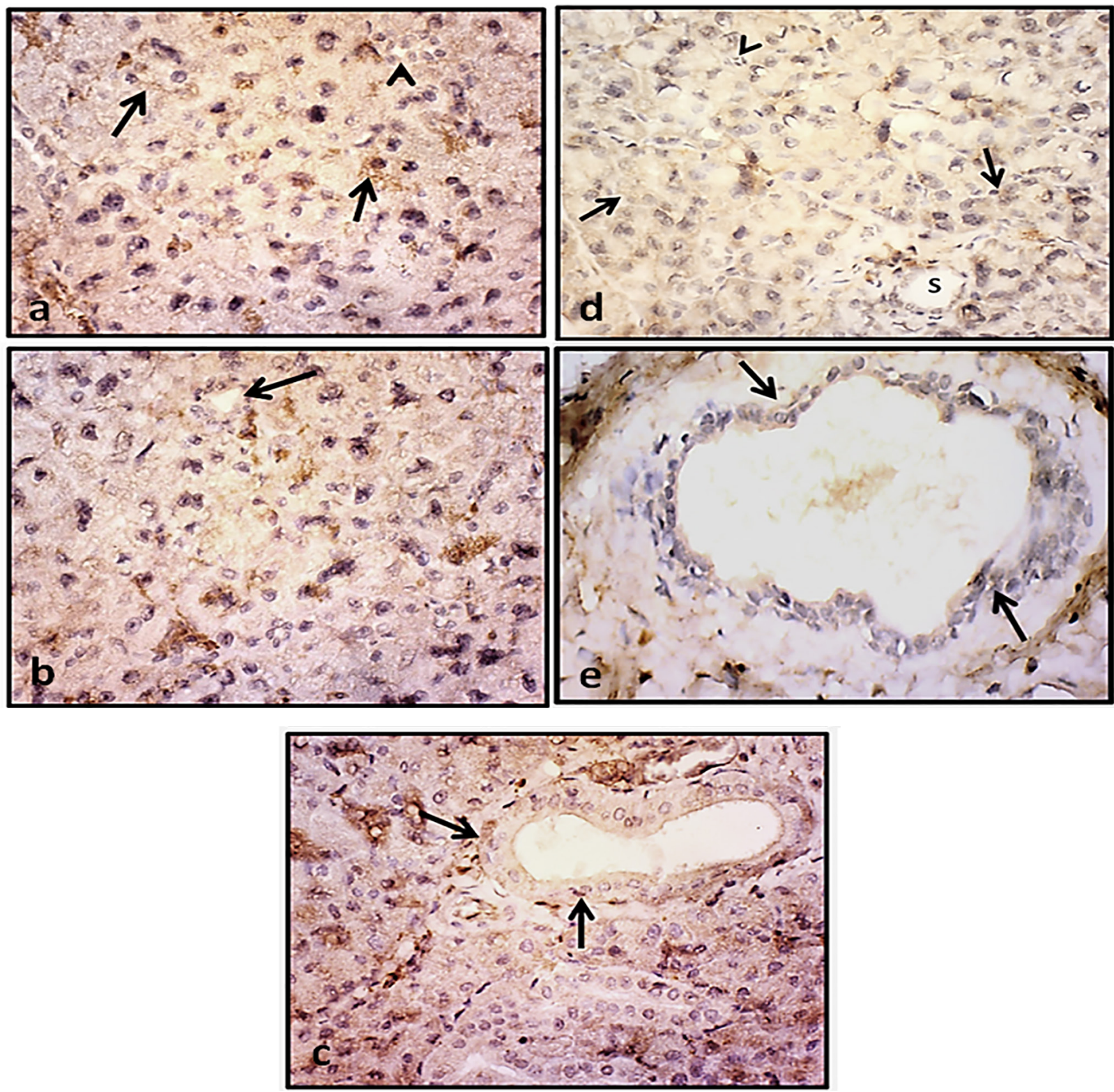

Fig. 6: A photomicrograph of PG of subgroup (IIIA) a- Diffuse positive cytoplasmic reaction and localized nuclear reaction in serous acini (black arrows). ID showed positive cytoplasmic and nuclear reaction (black arrow head). b- SD with positive cytoplasmic and nuclear reaction (black arrow). c- ED with positive cytoplasmic and nuclear reaction (black arrows). In subgroup (IIIB) d- Serous acini with positive nuclear and cytoplasmic reaction (black arrows). ID with negative nuclear and cytoplasmic reaction (black arrow head). SD with positive cytoplasmic and nuclear reaction (S). e- ED with diffuse cytoplasmic and localized nuclear reaction (black arrows) (anti-active caspase-3 antibody original magnification $\mathrm{x} 400$ ). 

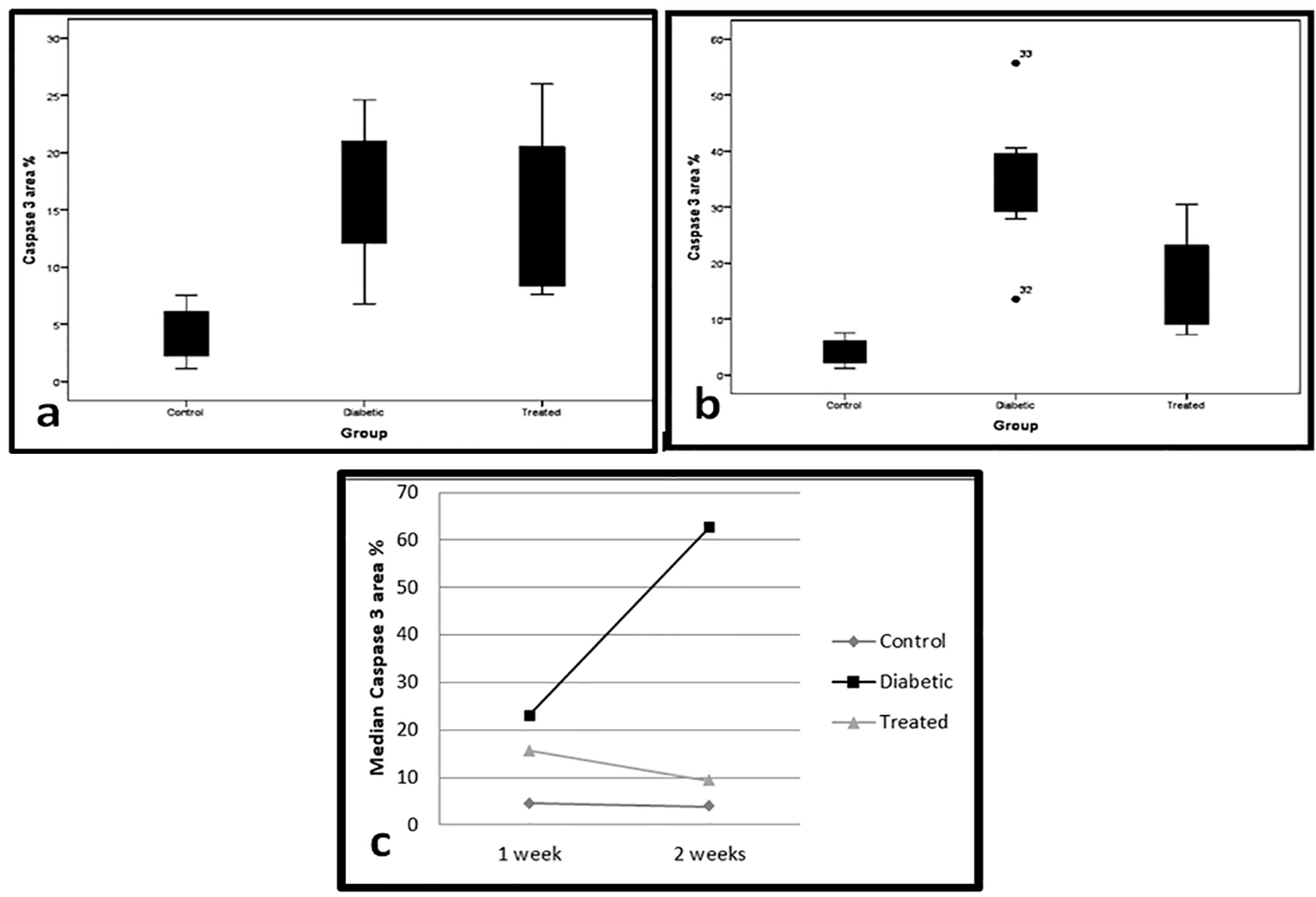

Fig. 7: a- Box plot representing median and range values for caspase- 3 area $\%$ in the three groups after 1 week. b- Box plot representing median and range values for caspase- 3 area $\%$ in the three groups after 2 weeks (circles represent outliers). c- Line chart representing changes in caspase-3 area\% within each group (effect of time).
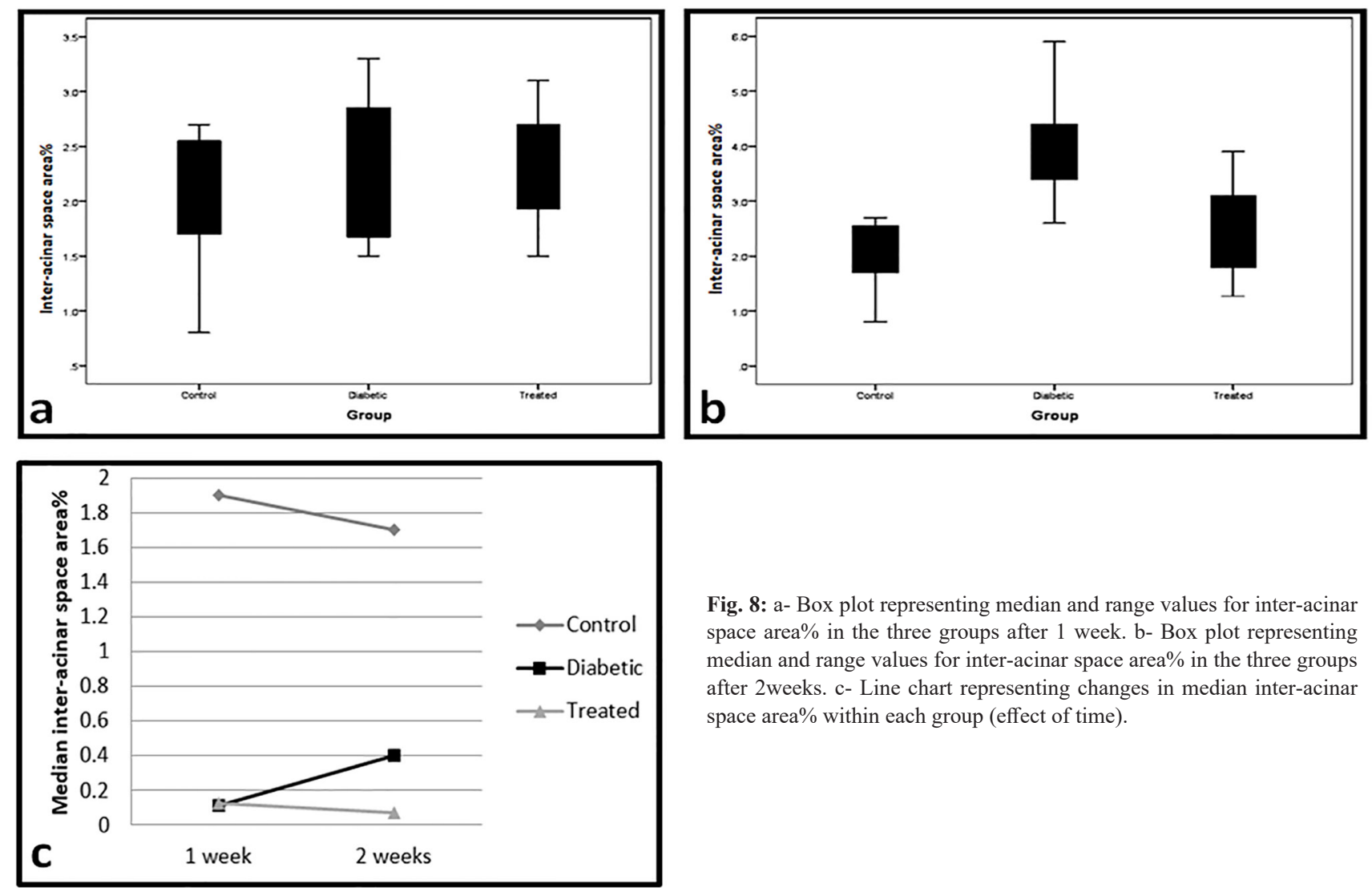

Fig. 8: a- Box plot representing median and range values for inter-acinar space area $\%$ in the three groups after 1 week. b- Box plot representing median and range values for inter-acinar space area $\%$ in the three groups after 2 weeks. c- Line chart representing changes in median inter-acinar space area\% within each group (effect of time). 

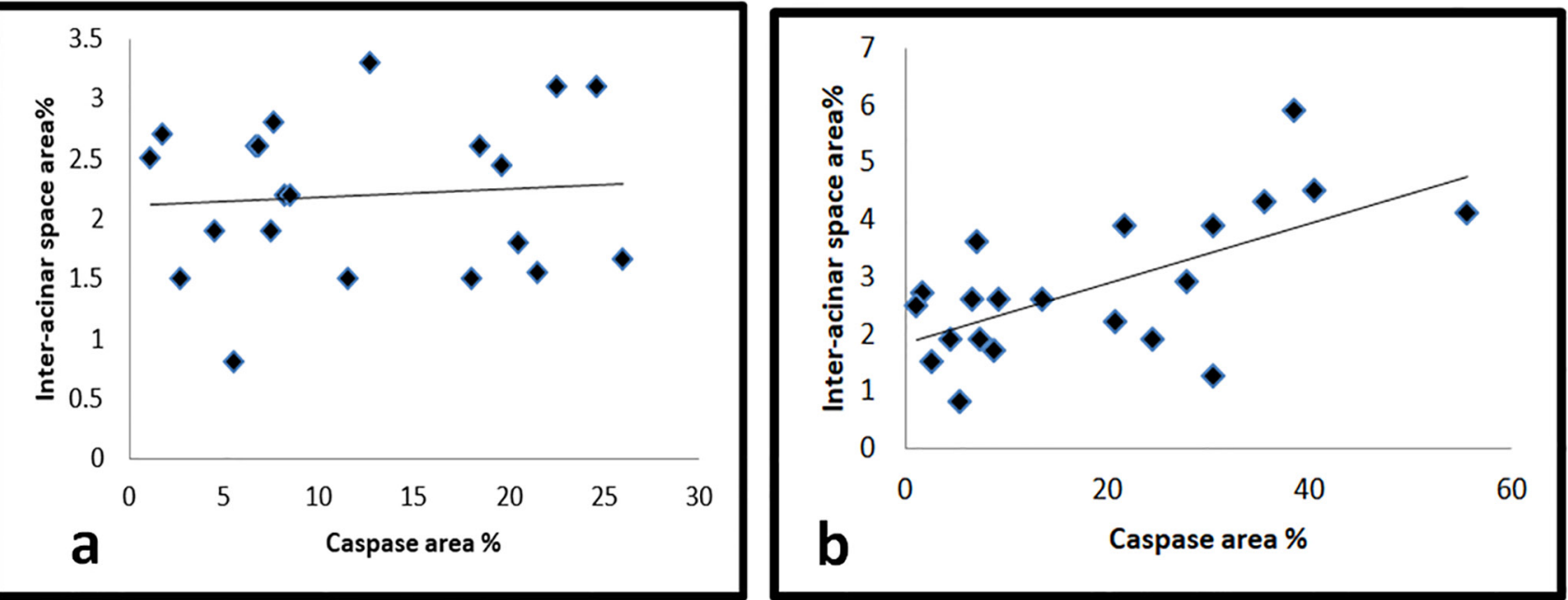

Fig. 9: a- Scatter diagram representing direct correlation between caspase- 3 area $\%$ and inter-acinar space area $\%$ after 1 week. b- Scatter diagram representing direct correlation between caspase- 3 area $\%$ and inter-acinar space area $\%$ after 2 weeks.

Table 1: Descriptive statistics and results of Kruskal-Wallis test for comparison between caspase-3 area\% in the three groups

\begin{tabular}{lcccccc}
\hline Time & & Control & Diabetic & Treated & $P$-value & Effect size (Eta Squared) \\
\hline \multirow{2}{*}{1 week } & Median (Range) & $4.5(1.12-7.5)^{\mathrm{B}}$ & $19.65(6.8-24.6)^{\mathrm{A}}$ & $18(7.6-26)^{\mathrm{A}}$ & \multirow{2}{*}{$0.002^{*}$} & 0.603 \\
& Mean (SD) & $4.25(2.47)$ & $16.74(6.46)$ & $15.61(7.52)$ & & 0.788 \\
\multirow{2}{*}{2 weeks } & Median (Range) & $3.8(1.5-6.5)^{\mathrm{C}}$ & $35.6(13.56-55.7)^{\mathrm{A}}$ & $20.8(7.19-30.5)^{\mathrm{B}}$ & $<0.001^{*}$ & $0.54(9.1)$ \\
& Mean (SD) & $4.07(1.89)$ & $34.64(12.92)$ & $17.54)$ & \\
\hline
\end{tabular}

*: Significant at $P \leq 0.05$, Different superscripts in the same row are statistically significantly different

Table 2: Descriptive statistics and results of Mann-Whitney U test for comparison between caspase-3 area\% at different follow up times within each group

\begin{tabular}{|c|c|c|c|c|c|}
\hline Group & & 1 week & 2 weeks & $P$-value & Effect size (d) \\
\hline \multirow{2}{*}{ Control } & Median (Range) & $4.5(1.12-7.5)$ & $3.8(1.5-6.5)$ & \multirow{2}{*}{0.902} & \multirow{2}{*}{0.103} \\
\hline & Mean (SD) & $4.25(2.47)$ & $4.07(1.89)$ & & \\
\hline \multirow{2}{*}{ Diabetic } & Median (Range) & $19.65(6.8-24.6)$ & $35.6(13.56-55.7)$ & \multirow{2}{*}{$0.009^{*}$} & \multirow{2}{*}{1.961} \\
\hline & Mean (SD) & $16.74(6.46)$ & $34.64(12.92)$ & & \\
\hline \multirow{2}{*}{ Treated } & Median (Range) & $18(7.6-26)$ & $20.8(7.19-30.5)$ & \multirow{2}{*}{0.565} & \multirow{2}{*}{0.024} \\
\hline & Mean (SD) & $15.61(7.52)$ & $17.54(9.1)$ & & \\
\hline
\end{tabular}

*: Significant at $P \leq 0.05$

Table 3: Descriptive statistics and results of Kruskal-Wallistest for comparison between inter-acinar spaces area\% in the three groups

\begin{tabular}{lcccccc}
\hline Time & & Control & Diabetic & Treated & $P$-value & Effect size (Eta Squared) \\
\hline \multirow{2}{*}{1 week } & Median (Range) & $1.9(0.8-2.7)$ & $2.44(1.5-3.3)$ & $2.2(1.5-3.1)$ & \multirow{2}{*}{0.712} & 0.073 \\
& Mean (SD) & $1.99(0.68)$ & $2.33(0.73)$ & $2.29(0.58)$ & & 0.532 \\
\multirow{2}{*}{2 weeks } & Median (Range) & $1.7(0.9-2.8)^{\mathrm{B}}$ & $4.1(2.6-5.9)^{\mathrm{A}}$ & $2.2(1.27-3.9)^{\mathrm{B}}$ & $0.003^{*}$ & $0.45(0.98)$ \\
& Mean (SD) & $1.71(0.6)$ & $4.03(1.09)$ & $2.4)$ & \\
\hline
\end{tabular}

*: Significant at $P \leq 0.05$, Different superscripts in the same row are statistically significantly different 
Table 4: Descriptive statistics and results of Mann-Whitney U test for comparison between inter-acinar spaces area\% at different follow up times within each group

\begin{tabular}{|c|c|c|c|c|c|}
\hline Group & & 1 week & 2 weeks & P-value & Effect size (d) \\
\hline \multirow{2}{*}{ Control } & Median (Range) & $1.9(0.8-2.7)$ & $1.7(0.9-2.8)$ & \multirow{2}{*}{0.442} & \multirow{2}{*}{0.419} \\
\hline & Mean (SD) & $1.99(0.68)$ & $1.71(0.6)$ & & \\
\hline \multirow{2}{*}{ Diabetic } & Median (Range) & $2.44(1.5-3.3)$ & $4.1(2.6-5.9)$ & \multirow{2}{*}{$0.011^{*}$} & \multirow{2}{*}{1.870} \\
\hline & Mean (SD) & $2.33(0.73)$ & 4.03 (1.09) & & \\
\hline \multirow{2}{*}{ Treated } & Median (Range) & $2.2(1.5-3.1)$ & $2.2(1.27-3.9)$ & \multirow{2}{*}{0.898} & \multirow{2}{*}{0.068} \\
\hline & Mean (SD) & $2.29(0.58)$ & $2.45(0.98)$ & & \\
\hline
\end{tabular}

*: Significant at $P \leq 0.05$

Table 5: Results of Spearman's correlation coefficient for the correlation between caspase- 3 area $\%$ and inter-acinar space area $\%$

\begin{tabular}{lcc}
\hline Time & Correlation coefficient & $P$-value \\
\hline 1 week & 0.082 & 0.723 \\
2 weeks & 0.591 & $0.005^{*}$ \\
\hline
\end{tabular}

*: Significant at $P \leq 0.05$

\section{DISCUSSION}

Diabetes mellitus is characterized by hyperglycemia that may cause production of free radicals in many tissues leading to destruction for their structure as well as function ${ }^{[11]}$. Green coffee can decrease the debilitating effects of diabetes because as it has hypoglycemic and antidiabetic effect. Moreover, GCBs have high content of one of the most valuable polyphenol called CGA that is considered as insulin sensitizer thus potentiating insulin action $^{[12,13]}$.

The PG was the tissue of choice as it is similar in structure and function to pancreas as well as it contributes by more than $50 \%$ of total volume of stimulated saliva and $20 \%$ of unstimulated saliva ${ }^{[14]}$.

In this study STZ $(40 \mathrm{mg} / \mathrm{kg})$ was the drug of choice as it is toxic to the insulin producing $\beta$-cells of pancreatic islets and it is widely used to induce type I diabetes in experimental animals as it has low mortality rate and high tolerance by the experimental animals ${ }^{[15,16,17]}$.

In this study, apoptosis was detected by immunohistochemical method (active caspase-3) as it considered direct, specific, sensitive indicator and a reliable method to detect and quantify apoptosis ${ }^{[18]}$.

Histologically, PG of control group in this study was formed of secretory end pieces and collecting ducts. Pyramidal shaped serous cells with basally located rounded nuclei, ID with cuboidal cells and SD of columnar cells with centrally placed nuclei and basal striation. ED lined by psuedostratified epithelium and surrounded by fibrous C.T, these normal findings are similar to other authors ${ }^{[19,20]}$.

In the current study, serous acini of PGs in diabetic group showed hyperchromatic, pleomorphic and pyknoticnuclei and cytoplasmic vacuolations. These findings are in parallel with ${ }^{[21,22]}$ and they related that to hyperglycemia that induce production of free radicals as a result of oxidative stress which lead to apoptosis of nuclei and cellular degeneration.

In herein study, spacing between serous acini of PG in diabetic subgroup IIB was observed. This finding is in similarity with other investigators ${ }^{[23]}$ who found the same effect in PG of diabetic mice as diabetes leads to generalized failure of growth, cellular degeneration, nuclear and cytoplasmic atrophy and disorganization of the cell membrane. In this study, desquamated cells observed between acini in diabetic subgroup IIB could be attributed to the negative effect of hyperglycemia on cell to cell acinar contact by reduction of E-cadherin expression ${ }^{[24,25]}$.

In the present study, flattening of ID cells in diabetic subgroup IIB and SD cells in both diabetic subgroups was detected, this result is in agreement to ${ }^{[26]}$ as epithelial cell height in the ID and SD of diabetic submandibular SG begins to change due to the direct effect of hyperglycemia and oxidative stress and indirect due to diabetic microangiopathy. SD of both diabetic subgroups showed loss of basal striation, this result agrees with ${ }^{[27]}$ and they accredited this due to degeneration of mitochondria which appeared swollen with loss of cristae.

Stagnated secretion in lumen of SD and ED as well as congested and dilated B.Vs around both ducts were observed in diabetic group of the present study, these findings are coinciding with what was detected in previous studies ${ }^{[27,28]}$ respectively. The changes in B.Vs could be attributed to the inflammatory process associated with D.M ${ }^{[29]}$, while the stagnated secretion may be linked to impaired salivary flow due to retardation of glandular function and reduction of secretory cell activity as a result of diabetic stress that affect endoplasmic reticulum expression of Aquaporin-5 "water channel protein" which has important role in water transport and exocrine secretion ${ }^{[30]}$.

In this study, ED of both diabetic subgroups showed discontinuity in epithelium lining and was surrounded by hyalinized C.T, these findings are in accordance with ${ }^{[19]}$. The changes that observed in the C.T could be related to the chronic hyperglycemia which cause disturbance in fibroblast remodeling activity ${ }^{[22]}$. 
In the current study, regarding the immunoistochemical examination and statistical analysis of anti-active caspase- 3 antibody in the PGs of both diabetic subgroups revealed increase of positive area $\%$ when compared to the control group, this result is in parallel with other authors ${ }^{[31]}$ who reported positive caspase- 3 reaction in SG epithelial cells of diabetic mice as hyperglycemia in diabetes leads to oxidative stress in which producing oxidative damage to the histones of the double chain DNA and affects expression of the DNA repairer enzyme which leads to cell death by apoptosis.

In this study, histological examination of diabetic treated subgroup IIIA showed little improvement in histological structure of PG, while the PGs of diabetic treated subgroup IIIB showed histological improvements nearly similar to the control group, these results are in parallel with ${ }^{[5]}$ that studied the antidiabetic effect of GCBs in alloxan induced diabetic rats using 2 different durations ( 8 and 15 days) and they reported decrease in blood glucose level compared to the diabetic control especially with longer duration, and they explained this due to the presence of CGA and caffeine that help in decreasing glucose intestinal absorption and reduce release of glucose by liver through inhibition of G-6-phosphatase.

In the present study histological examination of subgroup IIIB showed normal histological appearance of serous acini with minimal cytoplasmic vacuolation. These findings are in accordance with ${ }^{[32]}$ who reported pancreatic islets with nearly regular outlines and normal cell morphology with reduction in cytoplasmic vacuolation of STZ diabetic rats treated with caffeine.

In this study, histological examination of C.T around ED in diabetic treated subgroup IIIB appear almost normal as that of control group, this is in agreement with ${ }^{[33]}$ who reported acceleration in wound healing in form completely epithelialization and covering wound with granulation tissue of STZ diabetic rats treated with CGA for 2 weeks.

In the current study, regarding immunohistochemical examination and statistical analysis of anti-active caspase-3 antibody in the PGs of diabetic treated subgroup IIIB revealed decrease in positive area $\%$ when compared to the diabetic subgroup IIB. This is in accordance to ${ }^{[34]}$ who found the pretreatment with caffeinated coffee, decaffeinated coffee, and CGA protect neurons from induced apoptosis by inhibiting cleavage of caspase-3.

Caffeine helps in stimulating insulin secretion in presence of high blood glucose level due to sensitization of ryanodine receptor so that reducing oxidative stress caused by hyperglycemia and in return decreasing the initiative factor for apoptosis ${ }^{[35]}$. Moreover, it was found that, the CGA reduce expression of $\mathrm{Bax}$, increased the expression of Bcl-2 and lower the level of caspase- 3 in the pancreas of diabetic mice, this could be explained by the antidiabetic action of CGA that consider as natural insulin replacement with insulin like action which directly lowered the blood glucose level ${ }^{[36]}$.
In the current study, there is a statistically significant direct correlation between area $\%$ of both caspase- 3 and inter-acinar space after 2 weeks, this correlation could be explained as they are both sharing the same cause of their presence or absence which is the amount of produced ROS and the amount of oxidative stress produced by hyperglycemia ${ }^{[37]}$.

\section{CONCLUSIONS}

Diabetes mellitus has debilitating effects on acini and duct system of rats' parotid gland. Green coffee beans aqueous extract helps in improving histological picture and reducing the apoptotic rate of diabetic parotid gland in time dependent manner due to their hypoglycemic and antioxidant property.

\section{CONFLICTS OF INTEREST}

There are no conflicts of interest.

\section{REFERENCES}

1. Fukuoka C, Simoes A, Uchiyama T, Arana C, Abiko Y, Bhawal UK and Kuboyama N: The effects of low power laser irradiation on inflammation and apoptosis in submandibular glands of diabetes induced rats. PLOS ONE. (2017) 12(1):1-13.

2. Kharroubi AT: Diabetes mellitus the epidemic of the century. World Journal of Diabetes. (2015) 6(6):850-867.

3. Chamberlain J, Rhinehart AS, Shaefer CF and Neuman A: Diagnosis and management of diabetes. Synopsis of the American diabetes association standards of medical care in diabetes. Ann Intern Med. (2016) 164(8):542-552.

4. Stewart CR, Obi N, Epane EC, Akbari AA, Halpern L, Southerland JH and Gangula PR: Effects of Diabetes on Salivary Gland Protein Expression of Tetrahydrobiopterin and Nitric Oxide Synthesis and Function. Journal of Periodontology. (2016) 87(6):735-741.

5. Campos-florin J, Bardalesvaldivia J, Caruajulcaguevara L and Cuevallanos D: Antidiabetic effect of Coffea arabica, in alloxaninduced diabetic rats. Emirates Journal of Food and Agriculture. (2013) 25(10):772-777.

6. Kumar K, Fateh V, Verm B and Pandey S: Some herbal drugs used for treatment of diabetes. International Journal of Research and Development in Pharmacy and Life Sciences. (2014) 3(5):1116-1120.

7. Naveed M, Hejazi V, Abbas M, Kamboh AA, Khan GJ, Shumzaid M and XiaoHui Z: Chlorogenic acid (CGA): A pharmacological review and call for further research. Biomedicine \& Pharmacotherapy. (2018) 97:67-74. 
8. Kukner A, Colakoglu N, Ozogul C and Naziroglu MFT: The effects of combined vitamin $\mathrm{C}$ and $\mathrm{E}$ in streptozotocin-induced diabetic rat kidney. Clinical Reviews and Opinions. (2009) 1(2):29-36.

9. Bancroft JD, Suvarna K and Layton C: Bancroft's theory and practice of histological techniques ( $7^{\text {th }}$ ed.). Churchill Livingstone: Elsevier (2013) pp: $173-186$

10. Vyas D, Robertson CR, Stromberg PE, Martin JR and Micheal W: Epithelial apoptosis in mechanistically distinct methods of injury in the murine small intestine. Histol. Histopathol. (2007) 22(6):623-630.

11. Hidayat M, Tahir M and Shoro AA: Melatonin preserves the morphology of parotid gland damaged by streptozotocin induced diabetes. J Postgrad Med Inst. (2014) 28(2):128-132.

12. Meng S, Cao J, Feng Q, Peng J and Hu Y: Roles of Chlorogenic Acid on Regulating Glucose and Lipids Metabolism: A Review. Evidence-Based Complementary and Alternative Medicine. (2013) 2013:1-11

13. Jin S, Chang C, Zhang L, Liu Y, Huang X, Chen Z.: Chlorogenic Acid Improves Late Diabetes through Adiponectin Receptor Signaling Pathways in $\mathrm{db} /$ db Mice. PLOS ONE. (2015) 10(4):1-15.

14. Humphrey SP and Williamson RT: A review of saliva: Normal composition, flow, and function. J Prosthet Dent. (2001) 85(2):162-169.

15. Deeds MC, Anderson JM, Armstrong AS, Gastineau D, Hiddinga H, Jahangir A and Kudva Y: Single dose streptozotocin-induced diabetes: considerations for study design in islet transplantation models. Lab Anim. (2011) 45(3):131-140

16. Mostafavinia A, Amini A, Ghorishi SK, Pouriran R and Bayat $\mathrm{M}$ : The effects of dosage and the routes of administrations of streptozotocin and alloxan on induction rate of type 1 diabetes mellitus and mortality rate in rats. Laboratory animal research. (2016) 32(3): 160-165.

17. Islam $M$, Rupeshkumar $M$ and Reddy KB: Streptozotocin is more convenient than Alloxan for the induction of Type 2 diabetes. International Journal of Pharmacological Research. (2017) 7(1): 6-11.

18. Nambiar KS and Hegde V: Apoptosis detection modalities review. Int Dent Med J Adv Res. (2016) 2(1): $1-5$.

19. Moubarak R: The effect of hypercholesterolemia on the rat parotid salivary gland (histopathological and immunohistochemical study). Cairo Dent J. (2008) 24(1):19-28.
20. Hayat HN, Tahir TM, Munir MB and Sami SW: Effect of methimazole-induced hypothyroidism on histological characteristics of parotid gland of albino rat. Journal of Ayub Medical College Abbottabad. (2010) 22(3): 22-27.

21. Curcio S, Stefan LF, Randi BA, Dias MA, Silva RE and Caldeira EJ: Hypoglycemic effects of an aqueous extract of Bauhinia forficata on the salivary glands of diabetic mice. Pakistan journal of pharmaceutical sciences. (2012) 25(3):493-499.

22. Monteiro MM, D’Epiro TTS, Bernardi L, Fossati ACM, Santos MFD and Lamers ML: Long- and short-term diabetes mellitus type1 modify young and elder rat salivary glands morphology. Arch Oral Biol. (2017) 73:40-47.

23. Ror FN, Col LO, Moura EG, Jaciara MA and Caldeira EJ: N-Acetylcysteine, Anti-CD4/CD8 Antibodies, and Physical Exercise Reduces Histopathological Damage in Salivary Glands of Spontaneously Diabetic Mice. Austin Endocrinol Diabetes Case Rep. (2018) 3(1): 1013-1018.

24. Jin Z and El-Deiry WS: Overview of cell death signaling pathways. Cancer biology \& therapy. (2005) 4(2):147-171.

25. Li W, Zhang L, Chen X, Jiang Z, Zong L and Ma Q: Hyperglycemia Promotes the EpithelialMesenchymal Transition of Pancreatic Cancer via Hydrogen Peroxide. Oxidative medicine and cellular longevity. (2016) 2016.

26. Ersteniuk H, Kotyk $\mathrm{T}$, Dey $\mathrm{N}$, Yurakh $\mathrm{O}$ and Popadynets O: Effect of Hyperglycemia on the Excretory Ducts of the Submandibular Gland (Histologic Study). Galician Medical Journal. (2016) 23(4):1-5.

27. Mahmoud E and Mahmoud F: Effect of pomegranate peel extracts on submandibular salivary glands of streptozotocin induced diabetes in rats (histological, immunohistochemical and ultrastructural study). Journal of advances in biology and biotechnology. (2017) 13(3):1-15.

28. Zalewska A, Knas M, zendzian-Piotrowska M, Waszkiewicz N, Szulimowska J and Prokopiuk $\mathrm{SCH}$ : Antioxidant profile of salivary glands in high fat diet-induced insulin resistance rats. Oral diseases. (2014) 20(6):560-566.

29. Barrett EJ, Liu Z, Khamaisi M, King GL, Klein R, Klein B, Hughes TM, Craft S, Freedman BI, Bowde DW, Vinik AI and Casellini CM: Diabetic Microvascular Disease: An Endocrine Society Scientific Statement. J Clin Endocrinol Metab. (2017) 102(12): 4343-4410. 
30. Bhattarai K R, Lee H Y, Kim SH, Kim HR and Chae HJ: Ixerisdentata Extract Increases Salivary Secretion through the Regulation of Endoplasmic Reticulum Stress in a Diabetes Induced Xerostomia Rat Model. International journal of molecular science. (2018) 19(4):1059.

31. Masago R, Aiba-Masago S, Talal N, ImenezZuluaga F, Al-Hashimi I, Moody M and Dang H: Elevated proapoptotic Bax and caspase 3 activation in the NOD.scid model of Sjogrens syndrome. Arthritis Rheum. (2001) 44(3):693-702.

32. Abunasef SK, Amin HA and Abdel-Hamid GA: A histological and immunohistochemical study of beta cells in streptozotocin diabetic rats treated with caffeine. Folia Histochem Cytobiol. (2014) 52(1):42-50.

33. Bagdas D, Etoz BC, Gul Z, Ziyanok, S, Inan S, Turacozen O, Gul NY, Topal A, Cinkilic N and Tas S: In vivo systemic chlorogenic acid therapy under diabetic conditions: Wound healing effects and cytotoxicity/genotoxicity profile. Food Chem Toxicol. (2015) 81:54-61.
34. Kim J, Lee S, Shim J, Kim HW, Kim J, Jang YJ and Lee KW: Caffeinated coffee, decaffeinated coffee, and the phenolic phytochemical chlorogenic acid up-regulate NQO1 expression and prevent $\mathrm{H} 2 \mathrm{O} 2-$ induced apoptosis in primary cortical neurons. Neurochem Int. (2012) 60(5):466-474.

35. Bruton JD, Lemmens R, Shi CL, Person-Sjogren SG, Westerblad H, Ahmed M, Pyne NJ, Frame M, Furman BL and Islam MS: Ryanodine receptors of pancreatic $\beta$-cells mediate a distinct contextdependent signal for insulin secretion. FASEB J. (2003) 17(2):301-303.

36. Yin XL, Xu BQ and Zhang YQ: Gynura divaricata rich in 3, 5-/4, 5-dicaffeoylquinic acid and chlorogenic acid reduces islet cell apoptosis and improves pancreatic function in type 2 diabetic mice. Nutrition \& Metabolism. (2018) 15(1):73-79.

37. Roxo DF, Arcaro CA, Gutierres VO, Costa MC, Oliveira JO, Lima TF and Baviera AM: Curcuminm combined with metformin decreases glycemia and dyslipidemia, and increases paraoxonase activity in diabetic rats. Diabetology \& metabolic syndrome. (2019) 11(1):33-40. 


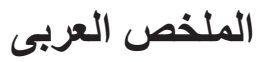

تحليل هيستولوجي و هيستوكيميائي مناعي لتأثير المستخلص المائي للبن الأخضر

\title{
على الغدد اللعابية النكافية في الفئران البيضاء المصابة بالسكري مئي المستحث
}

بالستريبتوزوتوسين

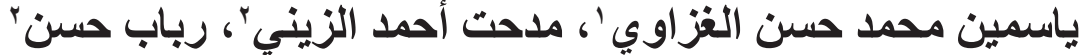

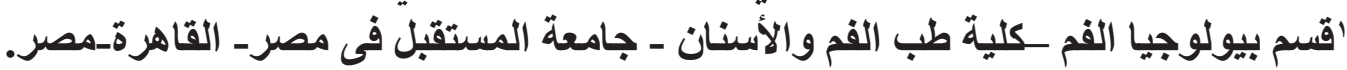

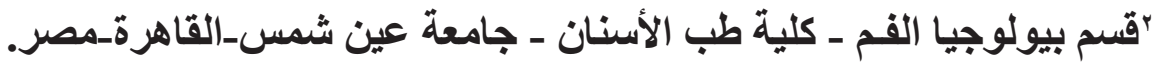

المقدمة: داء السكري هو اضطر اب شائع في ايض الكربو هيدرات التي تؤثر مضاعفاته بشكل كبير على جودة الحياة وطول العمر و زيادة تكاليف الرعاية الصحية. تعثبر القهوة الخضر اء واحدة من أكثر المشروبات استهلاكا في جميع أنحاء العالم وهي و احدة من أهم المصادر الرئيسية لحمض الكلوروجينيك المعروف بفو ائده البيولوجية المختلفة. الهدف: تقييم تأثنير المستخلص المائي للبن الأخضر على الغدد النكافيه في الفئران البيضـاء المصابه بالسكري المستحث بالسترييتوزوتوسين. مواد وطرق الاراسة: تم استخدام اثثنين وأربعين من الفئران الذكور البيضاء وقسمت بالتساوي إلى ثلاث مجمو عات

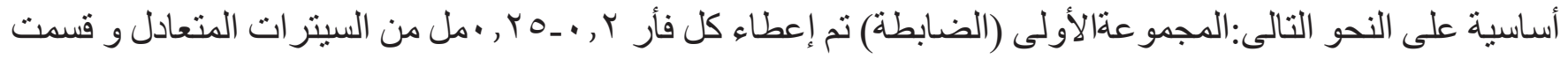

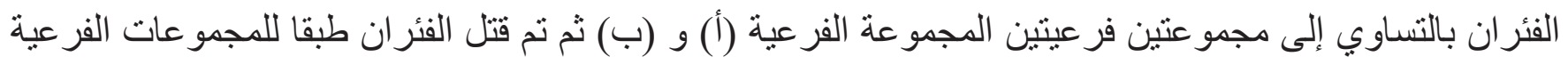

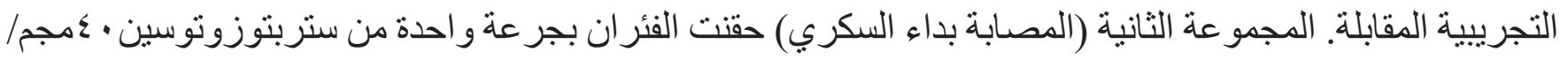

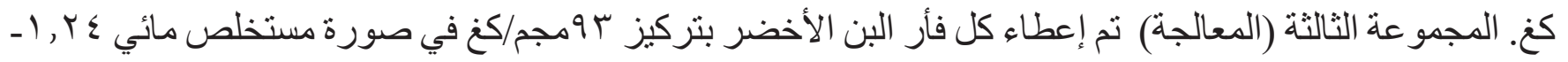
00, امل عن طريق الفم مرة واحدة يوميًا من حدوث مرض السكري حتى نهاية التجربة. تم تقسيم الفئران في المجمو عة إنة

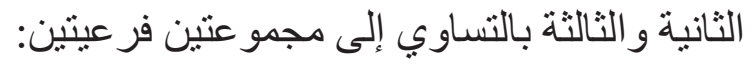
المجموعة الفرعية (أ) و المجموعة الفرعية (ب) [حيث تم قتل الفئران بعد أسبوع و بعد أسبوعين من الإصابة بداء

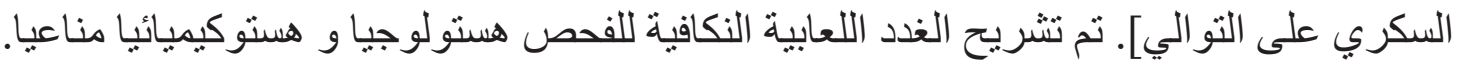

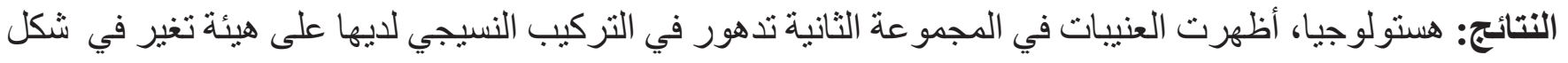

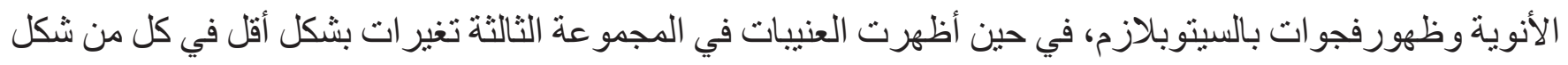

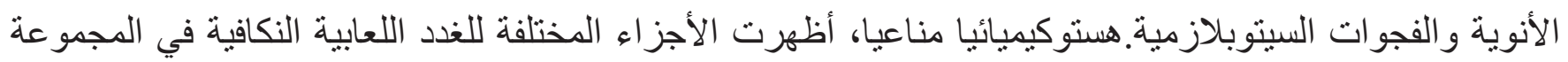

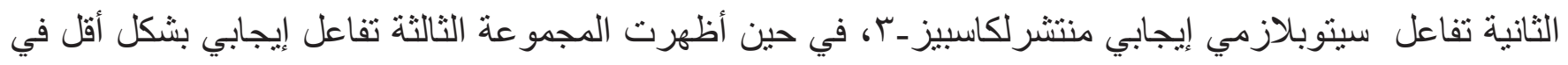

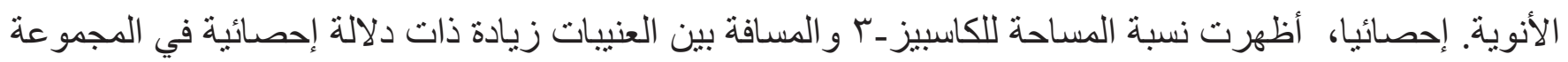

$$
\text { الفرعية (r ب))، و انخفاض ذي دلالة إحصائية في المجمو عة الفرعية (r ب). }
$$

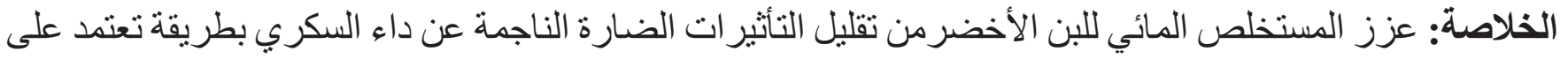

